\title{
Scenarios for sustainable heat supply and heat savings in municipalities - the case of Helsingør, Denmark
}

Ben Amer-Allam, Sara; Münster, Marie; Petrovic, Stefan

Published in:

Energy

Link to article, DOI:

10.1016/j.energy.2017.06.091

Publication date:

2017

Document Version

Early version, also known as pre-print

Link back to DTU Orbit

Citation (APA):

Ben Amer-Allam, S., Münster, M., \& Petrovic, S. (2017). Scenarios for sustainable heat supply and heat savings in municipalities - the case of Helsingør, Denmark. Energy, 137, 1252-1263.

https://doi.org/10.1016/j.energy.2017.06.091

\section{General rights}

Copyright and moral rights for the publications made accessible in the public portal are retained by the authors and/or other copyright owners and it is a condition of accessing publications that users recognise and abide by the legal requirements associated with these rights.

- Users may download and print one copy of any publication from the public portal for the purpose of private study or research.

- You may not further distribute the material or use it for any profit-making activity or commercial gain

- You may freely distribute the URL identifying the publication in the public portal

If you believe that this document breaches copyright please contact us providing details, and we will remove access to the work immediately and investigate your claim 


\title{
Scenarios for sustainable heat supply in cities - case of Helsingør, Denmark
}

\author{
Sara Ben Amer-Allam, ${ }^{\mathrm{a},}$, , Marie Münster ${ }^{\mathrm{a}}$, Stefan Petrovića \\ a'Department of Management Engineering, Technical University of Denmark, Kongens Lyngby, \\ Denmark, e-mail: sbea@dtu.dk \\ ${ }^{*}$ Corresponding author
}

\begin{abstract}
Abbreviations
$\mathrm{CHP}$ - combined heat and power

$\mathrm{CoM}$ - Covenant of Mayors

$\mathrm{COP}$ - coefficient of performance

$\mathrm{DH}$ - district heating

GIS - geographic information systems

LCT- Least Cost Tool

MSW - municipal solid waste

SEAP - Strategic Energy Action Plan

SEP - strategic energy planning
\end{abstract}

\begin{abstract}
Local climate action is not only a domain of large cities, but also smaller urban areas that increasingly address climate change mitigation in their policy. The Danish municipality of Helsingør can achieve substantial $\mathrm{CO}_{2}$ emission reduction by transforming its heat supply and deploying heat savings. In the paper we model the heating system of Helsingør from a socio- and private-economic perspective, develop future scenarios, and conduct an iterative process to derive optimal mix between district heating, individual heating and heat savings. The results show that in 2030 it is cost-optimal to reduce the heating demand by $20-39 \%$ by implementing heat savings, to deploy $33 \%-41 \%$ of district heating and reduce heating-related $\mathrm{CO}_{2}$ emissions by up to $95 \%$ compared to now. In 2050, the cost-optimal share of district heating in Helsingør is between 38-44\%. The resulting average heating costs and $\mathrm{CO}_{2}$ emissions are found to be sensitive to biomass and electricity price. Although the findings of the study are mainly applicable for Helsingør, the combined use of the Least Cost Tool and modelling with energyPRO is useful in planning of any heating and/or cooling supply and demand configuration, in any geographical region and scale.
\end{abstract}

\section{Highlights}

- Employing a combined energy modelling and Least Cost Tool method 
- Up to $39 \%$ heat savings and up to $39 \%$ district heating simultaneously implemented in Helsingør

- Heating-related $\mathrm{CO}_{2}$ reduction between 60 and 95\% compared to 2014

\section{Keywords}

heat savings; district heating; individual heating; $\mathrm{CO}_{2}$ emission reduction; energyPRO; Least Cost Tool

\section{Introduction}

Increasingly, urban areas are leading the way for energy efficiency and $\mathrm{CO}_{2}$ emission reduction actions. Currently, heating constitutes almost half of the total European energy consumption [1]. In Denmark, heat supply planning is one of the areas, where municipalities enjoy relatively significant influence, especially in relation to district heating [2]. Our case study, Helsingør (also known as Elsinore), Denmark, has an area of $122 \mathrm{~km}^{2}$ and has approximately 62,000 inhabitants. It is located in North Eastern part of the Zealand island, about $50 \mathrm{~km}$ from the Danish capital, Copenhagen. The municipality has been involved in regional strategic energy planning efforts and is currently identifying the range of its local climate action. Helsingør aspires to reduce $\mathrm{CO}_{2}$ emissions by $20 \%$ in 2020 , reach a level of one tonne of $\mathrm{CO}_{2} /$ inhabitant in 2030 and become $\mathrm{CO}_{2}$ neutral in 2050. Heating in the municipality constitutes about a third of emissions, so implementing heat savings in buildings, switching oil- and natural gas-based individual supply to renewables or expanding the district heating network, which in the future is expected to be primarily based on renewable fuels, will help Helsingør achieve its climate mitigation goals.

One of the most common approaches to promoting local climate initiatives is the strategic energy planning (SEP). The Danish Energy Agency defines SEP in the following way: "Strategic energy planning in the municipalities is about long-term planning. The municipality can contribute to a long-term development towards a fossil-free energy supply and other municipal and national climate and energy related goals. SEP encompasses all types of energy supply and demand in all sectors (households, municipal and other public service, private service, industrial production and transport)" [3]. In Europe, Strategic Energy Action Plans (SEAPs) are promoted through the Covenant of Mayors (CoM). They focus on buildings, equipment/facilities and urban transport, but also on local electricity production and local heating/cooling generation. Industry is on the other hand not a target sector [4]. The first SEAPs show how the Covenant signatories will reach their commitments by 2020. In May 2014, the signatories of the CoM agreed to reduce their GHG emissions with $170 \mathrm{Mt} \mathrm{CO}_{2}$ eq, which equals $28 \%$ of their total emissions and $15 \%$ of the $\mathrm{EU}$ GHG emissions reduction target [5]. This article identifies cost-efficient and renewables-based heating supply as part of developing a strategic energy plan for the municipality of Helsingør.

Developing a SEAP involves establishing a baseline emissions inventory including an energy balance. When focusing on the energy sector it may however be beneficial to make more detailed 
system analyses taking into account the fluctuations in demand and production, which we handle using the energy system analysis tool energyPRO.

In the literature, municipal energy scenarios have been modelled and analysed e.g. for cities in Denmark [6,7], Greece [8], Brazil [9], Italy [10] and Poland [11]. Various urban energy models are also reviewed by $[12,13]$. The works concentrating specifically on local heat planning include: using statistical methods to determine DH feasibility in a Russian city [14], using a spreadsheet model and optimization model TIMES-DK for heat supply planning in a Danish housing community [15], modelling design and operation of a distributed energy system and a decentralised district heating network with an optimization model [16], quantitative scenario analysis of socio-economic feasibility of energy renovations and renewable energy supply in Copenhagen up to 2070 [17], determining optimal dispatch of large-scale heat pumps in Copenhagen using Balmorel model [18].

Nielsen and Möller [19], Sperling and Møller [6] have used Geographic Information Systems (GIS) data for mapping heat consumption in Denmark. In addition to being used in industry, energyPRO has been applied in several peer-reviewed publications, for example to compare energy storage systems [20], analyse the operation of CHP (combined heat and power) plants on electricity markets [21,22] and their possibilities for balancing services in Denmark [23] and Germany [24]. Moreover, [25] has used energyPRO for conducting an energy system analysis of a Hungarian town.

The novelty of this paper lies in linking a detailed representation of heat savings in the building stock and district heating modelling using energyPRO through an iterative calculation conducted in a spreadsheet-based Least Cost Tool. Our methodology allows identifying optimal mix of heat savings, district heating expansion and individual heat supply, given specific policy scenario. Since this work is part of the progRESsHEAT [26] project, our analyses will also contribute to the municipal energy policy development in Helsingør and other municipalities in Europe.

In this paper, we model Helsingør's heating system from a socio- and private-economic perspective, develop future scenarios, and conduct an iterative process of cost curve analysis and energy modelling to derive optimal supply and savings mix. As a result, the following research questions are answered:

- Which future energy systems setups for Helsingør are viable?

- What levels of district heating and heat savings are feasible given various scenarios?

- How are the results sensitive to the used biomass and electricity price?

While a combination of a GIS tool and energyPRO has already been used by Nielsen and Möller [27], our work is novel in the way it provides a holistic methodology to derive the optimal mix of district heating (including expansion), individual heating and heat savings, which are intertwined and modelled dynamically. Moreover, both the socio- and private-economic perspective are considered. 


\section{Input data}

\subsection{Current energy system}

District heating in Helsingør municipality is supplied from a natural gas-fired CHP and boilers located within its boundaries and from a municipal solid waste (MSW) incineration plant Norfors and natural gas units located in neighbouring Hørsholm. In the model, two district heating grids are represented: one for Helsingør municipality and the other for Norfors (supplying Helsingør and several other municipalities), connected with a bidirectional heat capacity transmission line. Individual heating (modelled in the Least Cost Tool) consists of oil and natural gas boilers and few heat pumps and biomass boilers.

\subsection{Local renewable energy resources}

The locally-sourced energy crops and forest wood potential for energy production in Helsingør municipality is $44.5 \mathrm{GWh}$ [28]. The solar energy available is up to $162 \mathrm{GWh}$ on roofs and 139 GWh within agricultural area [28]. The possible heat sources for heat pumps are: a nearby lake, wastewater or seawater [28], as well as low-temperature industrial excess heat, amounting for 100 GWh potential [29]. Additionally, there is a potential for an air-to-water heat pump.

\subsection{Scenarios and perspectives}

This study focuses on two years: 2030 and 2050. The scenarios for 2030 are examined from two perspectives: a socio-economic (denoted with "A") and a private-economic (denoted with "B"). The year 2050 is analysed only from the socio-economic perspective due to the volatility of longterm prediction of tax policies. The socio-economic perspective includes externalities such as $\mathrm{NO}_{\mathrm{X}}$ and methane taxes, $\mathrm{CO}_{2}$ taxes and quotas, but excludes energy taxes and subsidies; the discount rate is $2 \%$, following Drupp et al. [30]. The private-economic perspective includes energy taxes and subsidies and applies the following discount rates: $0.99 \%$ for investments in district heating plants and grid, $2.18 \%$ for heat savings and heat installations in large buildings (e.g. public offices) and $4.46 \%$ for investments in heat savings and heat installations in small buildings (e.g. single/multi- family houses). We assume $1 \%$ yearly inflation. The discount rates are different for these three categories, because their current conditions for loan taking are also different.

Table 1 shows the scenarios and perspectives analysed in this study.

Tab. 1: Scenarios and perspectives in this study.

\begin{tabular}{|c|c|c|c|c|}
\hline Year & Scenario description & $\begin{array}{c}\text { Scenario } \\
\text { perspective }\end{array}$ & $\begin{array}{c}\text { Socio- } \\
\text { economic } \\
\text { perspective }\end{array}$ & $\begin{array}{c}\text { Private- } \\
\text { economic } \\
\text { perspective }\end{array}$ \\
\hline 2030 & $\begin{array}{c}\text { Helsingør: woodchip CHP } \\
\text { and boiler } \\
\text { Norfors: natural gas boilers } \\
\text { and MSW CHP and boiler }\end{array}$ & $\begin{array}{c}\text { BAU2030A } \\
\text { (Business As } \\
\text { Usual) }\end{array}$ & $\begin{array}{c}\text { XAU2030B } \\
\text { Business As } \\
\text { Unsual })\end{array}$ & $\mathbf{X}$ \\
\cline { 2 - 5 } & $\begin{array}{c}\text { DH setup as above; } \\
\text { additionally, a policy of }\end{array}$ & $\begin{array}{c}\text { RES2030A } \\
(\text { REnewableS })\end{array}$ & $\mathbf{X}$ & \\
\hline
\end{tabular}




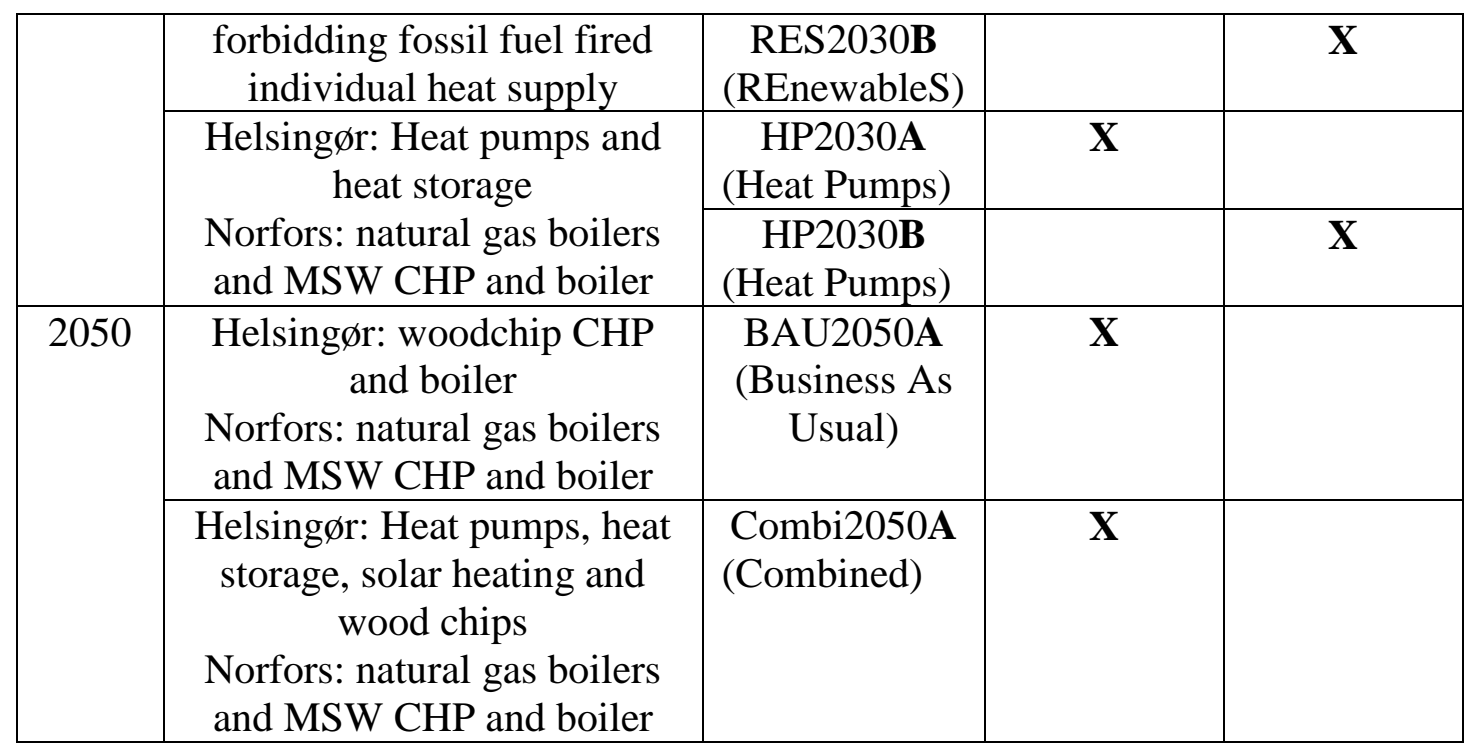

In 2030, three scenario types are examined: BAU, RES and HP. Due to their age, all district heating plants are assumed decommissioned by 2030 and a biomass CHP will be implemented in Helsingør in 2018, making this technology choice the business as usual (BAU) scenario. Norfors has a renewed capacity of the same type of energy units as currently. In RES scenarios, the basic setup of the district heating production system is the same. The difference comes from prohibiting existing and new individual natural gas and oil boilers, as discussed in the Danish political agreement from 2012 [31] and considering Helsingør's goal to decrease $\mathrm{CO}_{2}$ emissions from the municipality to $1 \mathrm{t} \mathrm{CO}_{2}$ per capita by 2030 , as well as the regional goal of achieving fossil fuel-free electricity and heat supply in 2035. In HP scenarios the district heating production in Helsingør is based exclusively on heat pumps and heat storage, since locally-sourced biomass in the municipality is too scarce to cover all the demand.

In 2050, two scenarios are examined: BAU and Combi. Due to their age, all district heating plants are assumed decommissioned by 2050 and a new biomass CHP is implemented in Helsingør in 2050, making this technology choice the business as usual (BAU) scenario. Norfors has a renewed capacity of the same type of energy units as in 2030. Combi2050 scenario is based on solar heating, heat pumps and thermal storage. The capacities were decided in an iterative process, using energyPRO, considering the renewable resources available in Helsingør.

\subsection{Prices, taxes and subsidies}

The district heating in Denmark is non-profit, thus the price is determined by the costs minus the revenue from electricity sales on the spot market. In BAU2030 scenario an additional source of revenue is added to electricity sales: the subsidy for electricity production on biomass.

The costs common for the socio- and private-economic perspective are:

- Fuel purchase costs

- Unit operation and maintenance

- Annuitized network and capacity investments

- Administration costs (e.g. employment)

- $\mathrm{CO}_{2}$ quotas, $\mathrm{CO}_{2}$ tax, methane tax and NOx tax 
In the private-economic analysis, VAT and energy tax are added, based on the Danish Tax office. For details, please see Appendix A.

Electricity and heat capacities, derived from the Danish Energy Producers Count, are applied efficiencies and costs from similar technologies from the Technology Catalogue developed by the Danish Energy Agency [32].

Fuel prices are shown in Appendix A. For 2030, they are projected by the Danish TSO Energinet.dk [33]. For 2050, they are forecasted by Fraunhofer ISI, using [34] and [35]. The electricity price profile for 2030 is created by scaling the average hourly spot electricity price profile (2011-2015) for Eastern Denmark to the average price forecasted by Energinet.dk in 2030: 57.4 EUR/MWh. The electricity price profile for 2050 is created by scaling the average price profile (2011-2015) to the average price forecasted for 2050 in Denmark by Fraunhofer ISI: 67.7 EUR/MWh, based on [34] and [35].

\section{Methods}

The methodology in this study consists of: aggregation of building stock, district heating modelling with energyPRO and iterative modelling of heat supply and heat savings costs with a purposelydeveloped Least Cost Tool (LCT). Figure 1 shows the data flow between the models used directly: Least Cost Tool and energyPRO, and models providing data: Forecast and Invert/EE-Lab.

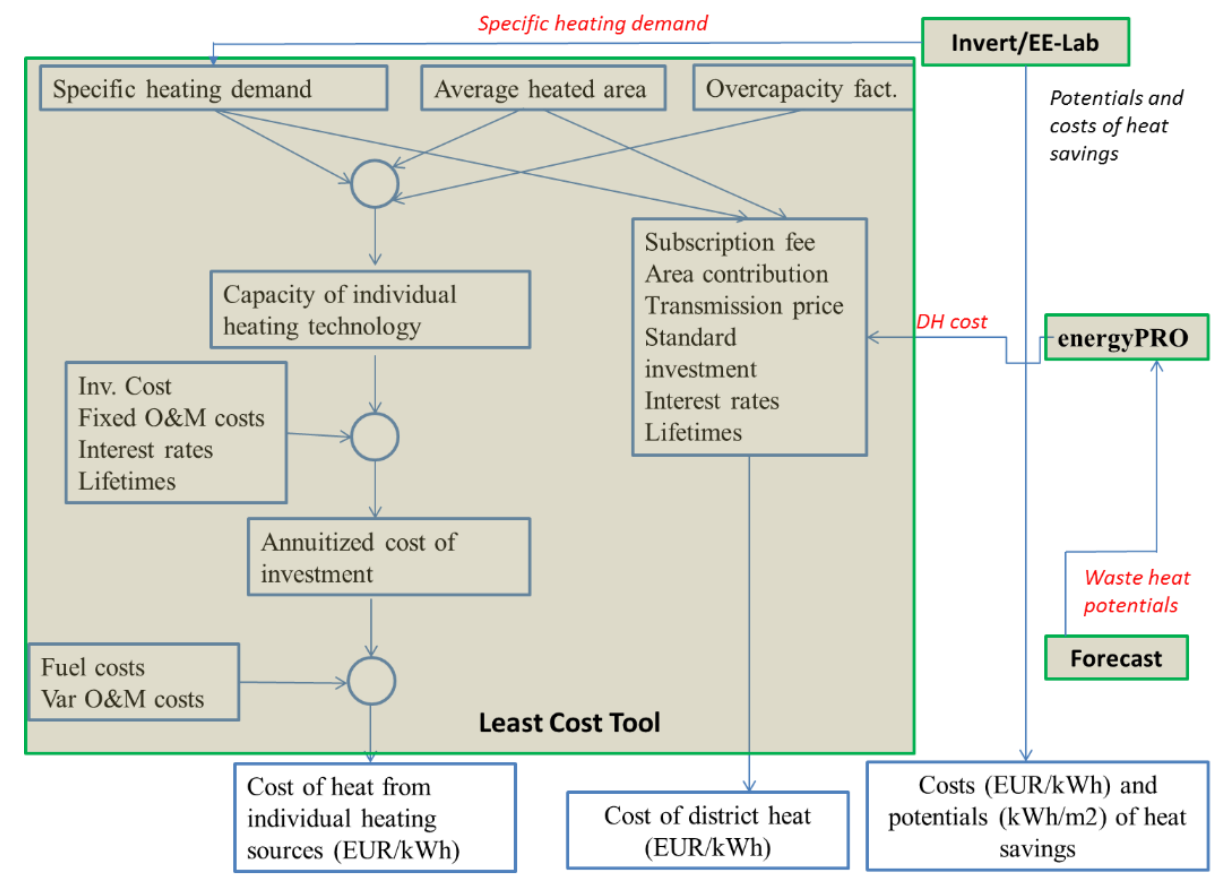

Fig. 1 Data flow between models used in this study. The two main elements are energyPRO and Least Cost Tool.

The energyPRO tool is used to calculate the costs of district heating (DH) production, depending on changes in the heat demand, which can increase if DH expansion takes place or decrease if heat 
savings are implemented. The costs of individual supply and heat savings are compared with district heating costs within the Least Cost Tool (LCT), considering the overcapacity factor for individual heat installations, specific heating demand and average heated area. This process is discussed in detail in section 3.2.

The overcapacity factor (OCF) represents the ratio between heating demand in the coldest hour in a year (peak heating demand) and an average hour in the coldest month and is used to scale the capacity (CAP) of individual boilers to cover the heating demand in the coldest hour in a year.

$$
C A P=\frac{H D_{S} \cdot A_{A V} \cdot s_{\text {cold.m }} \cdot O C F}{T_{\text {max.m }}}
$$

According to Danish Technology data for energy plants [36], an average existing single-family house has an annual heating demand (HD) of 16.8 MWh and peak heating demand of $7 \mathrm{~kW}$. If the share of annual heating demand in the coldest month (January) is assumed to be $15 \%$, the resulting overcapacity factor is equal to 2 .

The least cost solution is found by comparing costs of heat savings, DH and individual supply. If individual or DH supply increases or decreases, new costs are calculated and the iterative process continues until definitive results are found, as shown in Figure 2 and explained in section 3.2.

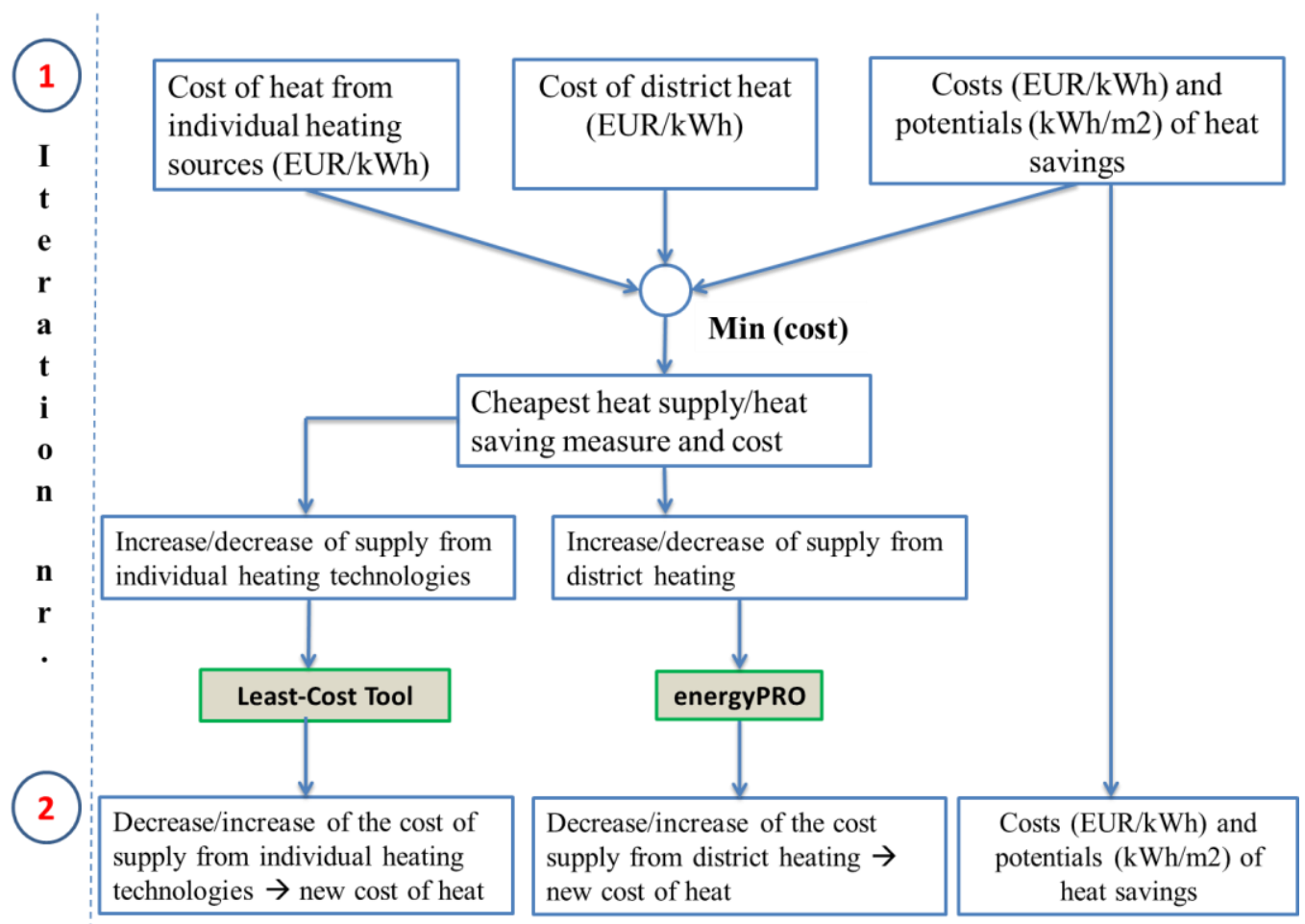

Fig. 2 Least-cost calculation iterations between the Least Cost Tool and energyPRO. 


\subsection{Building aggregation}

The cost of DH depends on the geographical location, related to the distance to existing district heating grids. Therefore, we divide Helsingør into four types of areas: DH areas, Next-to-DH areas, Individual areas and Scattered buildings. Additionally, in this study, buildings in Helsingør are aggregated according to their geographical location, age and use.

In DH areas the majority of buildings are supplied by district heating. The presence of transmission lines in the municipality allows to distinguish six such areas in Helsingør. Some buildings located in $\mathrm{DH}$ areas are not connected to the $\mathrm{DH}$ network, thus they require investments in connecting pipes and heat exchangers. Next-to-DH areas share a border with existing DH areas, but are not supplied by district heating. To connect the buildings located in Next-to-DH areas to the district heating network, investments in distribution pipes, connecting pipes and heat exchangers are necessary. Individual areas are not supplied by district heating and do not share a border with existing district heating areas. To connect the buildings located in Individual areas to DH, investments in transmission pipes and distribution pipes, connecting pipes and heat exchangers are necessary. Scattered buildings represent individual buildings scattered across the municipality. We exclude the possibility of expansion of district heating to these areas, due to their location far from the transmission grid.

Figure 3 depicts the location of DH areas and areas with expansion potential in Helsingør.

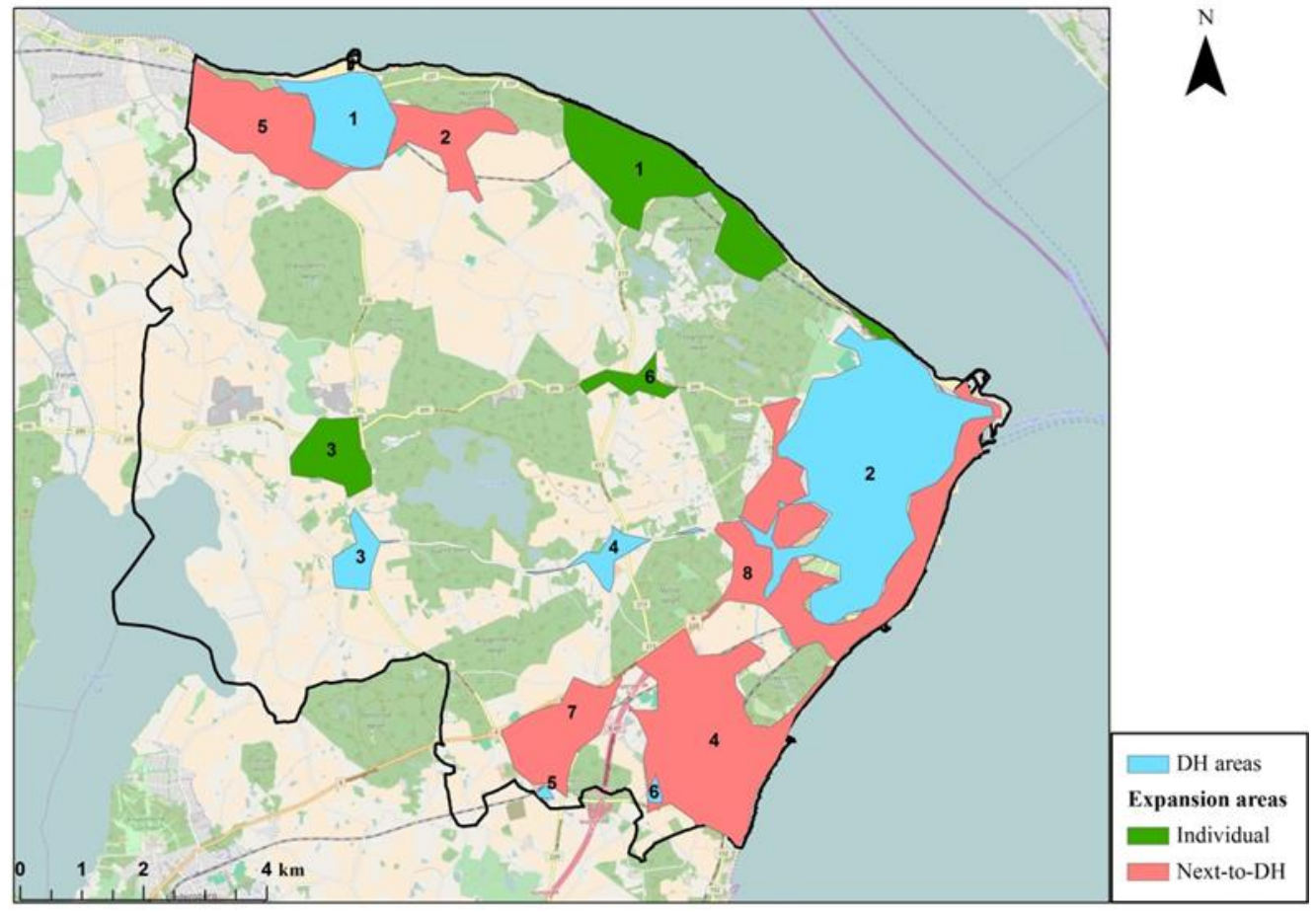

Fig.3 Administrative boundaries of Helsingør municipality and division into DH areas (blue) and expansion areas: Next-to-DH areas (pink) and Individual areas (green) 
In Helsingør, DH areas cover the majority of the building stock (shown as overall heated area in Figure 4).

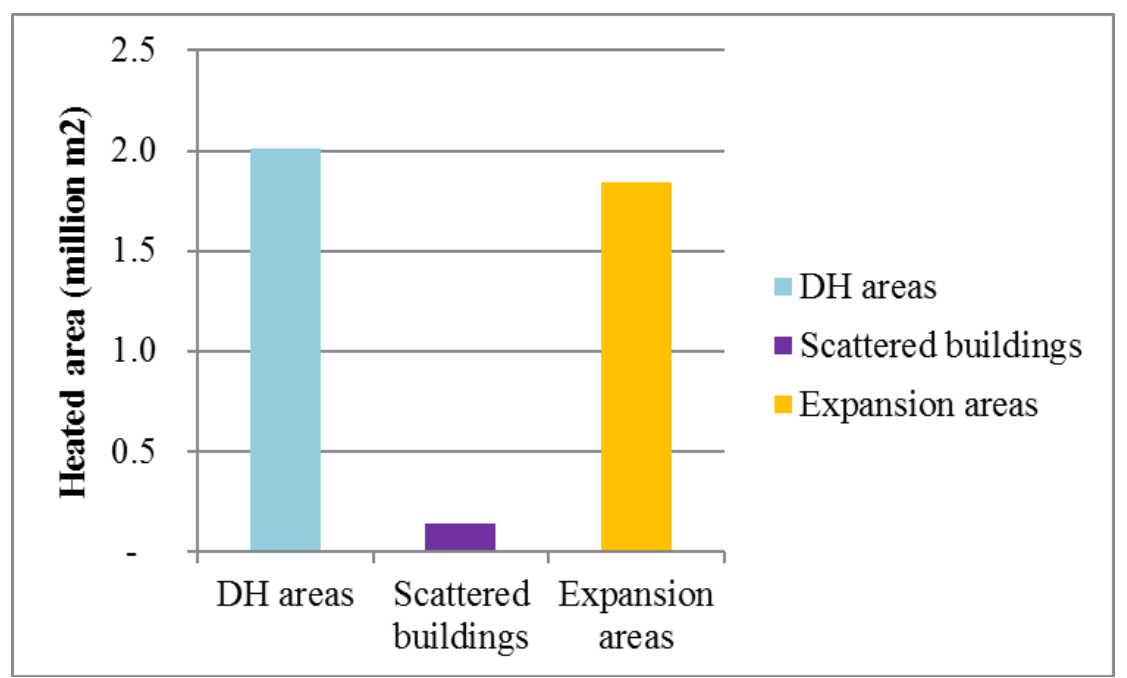

Fig. 4 Aggregation of building stock (heated area) per area type divided into: DH areas, expansion areas (Next-to-DH, and Individual) and Scattered buildings (million $\mathrm{m}^{2}$ ).

The heat for buildings located within DH, Next-to-DH and Individual areas can be provided by $\mathrm{DH}$ or individual heating sources. Additionally, their heating demand can be reduced by implementing heat saving measures. The disconnection from DH is not allowed in our analysis. For the Scattered buildings only the individual supply and heat saving measures are possible.

The costs of heat saving measures depend on the construction period and use of buildings. The use of buildings determines the annual heating demand and subsequently the costs of heat savings. The aggregation of building stock according to construction period and use is adopted from the Invert/EE-Lab model [37] and presented in Figure 5.

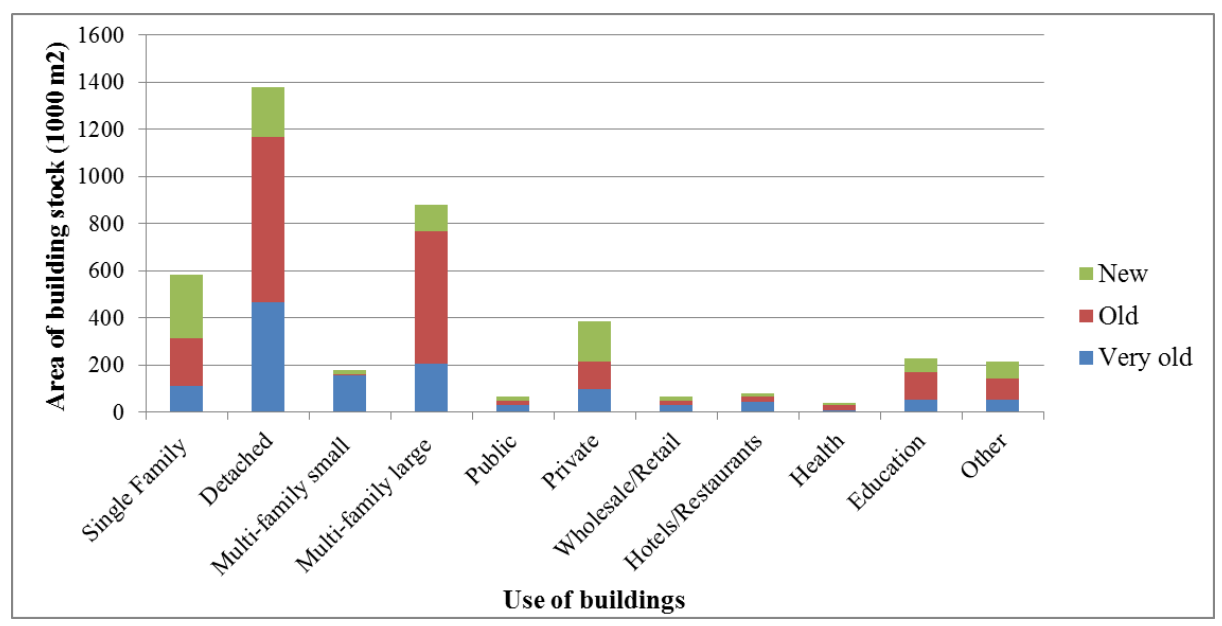

Fig. 5 Area of building stock aggregated according to use and construction period $\left(1000 \mathrm{~m}^{2}\right)$ 
"Very old", "Old" and "Normal" buildings were built before 1950, between 1951 and 1978 and after 1979, respectively. Buildings of the same use belong to the same use-group; buildings built in the same construction period belong to the same age-group. Buildings within the same agegroup and use-group located in the same type of geographical area belong to the same group of buildings. According to the adopted aggregation there are 3 age-groups, 11 use-groups and 4 geographical areas; in total 132 building groups.

\subsection{Least Cost Tool}

Technically, every building can be supplied with heat and domestic hot water either from an individual heating source or from district heating. When we consider economy, a certain heat density is needed for district heating to achieve cost-effectiveness. This issue is well elaborated in [38]. It is similar with heat saving measures: space heating demand can technically be reduced to very low levels, but their costs vary greatly within the building stock. With the exception of natural gas boilers which require grid connection the cost of heat from individual heating sources does not vary much depending on the geographical position, construction period and the use of building.

To add to the complexity, the choice of a new type of heat supply or heat savings for a building can also influence the costs of other heat supply alternatives; additionally, it can have an effect on the costs of heat supply and heat savings in other buildings. For example, implementing heat saving measures in a building connected to district heating will reduce its heat demand, increase the cost per unit of produced district heating and thus increase the cost of district heat for other DH consumers connected to the same grid. Consequently, DH becomes less competitive in the remaining buildings compared to individual heating alternatives and heat savings. However, the impact of this change is only significant in case of substantial heat savings in a larger group of buildings or a part of a city. Thus, in order to find the least expensive heat supply alternative, it is necessary to take into account $\mathrm{DH}$, individual heating options, heat savings and even combinations of heat savings and heat supply.

The prices of heat savings in buildings are adopted from Invert/EE-Lab model. The individual heat costs are calculated based on the Danish Technology Catalogue. Within the present paper, the competition between heat savings, DH and individual heat supply is analysed using the Least Cost Tool (LCT). LCT is spreadsheet based and calculates the cost-optimal heat supply configuration through an iterative procedure. The iterations are driven by cost of heat supply, i.e. when the average heat supply price in the municipality stays below a certain threshold between two consecutive iterations, the iteration procedure stops. The actual heat supply configuration is proclaimed as the cost-optimal.

\subsection{Modelling with energyPRO}

energyPRO, developed and maintained by EMD International [39], is a commercial modular software for techno-economic analyses of energy projects. energyPRO can conduct an operation optimization accounting for e.g. weather, technical properties of units, maintenance costs, fuel prices, taxes and subsidies etc. The optimization is done via an operation strategy - defined by user or calculated automatically (minimizing the net production cost). A set of power curves e.g. for fuel consumption or electricity and/or heat and/or cooling production describes each production unit. The operation optimization can be made against fixed tariffs for electricity or variable spot market 
prices. The length of the calculation step is between 10 minutes and 1 hour and the length of the optimization period is 1 month or 1 year.

In this study, the energyPRO tool is used to calculate the costs of district heating production, depending on changes in the heat demand, which can increase if district heating expansion takes place or decrease if heat savings are implemented. The costs of individual supply and heat savings are calculated in the spreadsheet model. Both district heating and individual supply costs are compared with each other in an iterative process until definitive results are found. While year 2013 was modelled for calibration purposes, in this paper we focus on year 2030 and 2050 for calculating the optimal heat supply mix.

\subsection{Calculation of $\mathrm{CO}_{2}$ emissions from scenarios}

The $\mathrm{CO}_{2}$ emissions calculated concern only heat supply. For each scenario they are a sum of emissions from district heating relative to the size of production (calculated by energyPRO) and emissions from individual supply, depending on fuels used. The $\mathrm{CO}_{2}$ emission factors used are shown in Appendix B. We allocate emissions from CHPs proportionally to their heat output. Since 2030 and 2050 are the years of focus, we assume that electricity in Denmark is $100 \%$ based on renewable fuels - thus heat pumps are also assigned no emissions. Moreover, biomass is considered a $\mathrm{CO}_{2}$-neutral resource.

\section{Results}

\subsection{Heat supply mix}

Figure 6 shows the heat supply mixes in the base year and cost-optimal heat supply mixes for the six analysed scenarios in 2030. The difference between the total heat supplied in the base year and in the alternative scenarios originates from heat savings. In none of the scenarios oil boilers are chosen, due to their high cost.

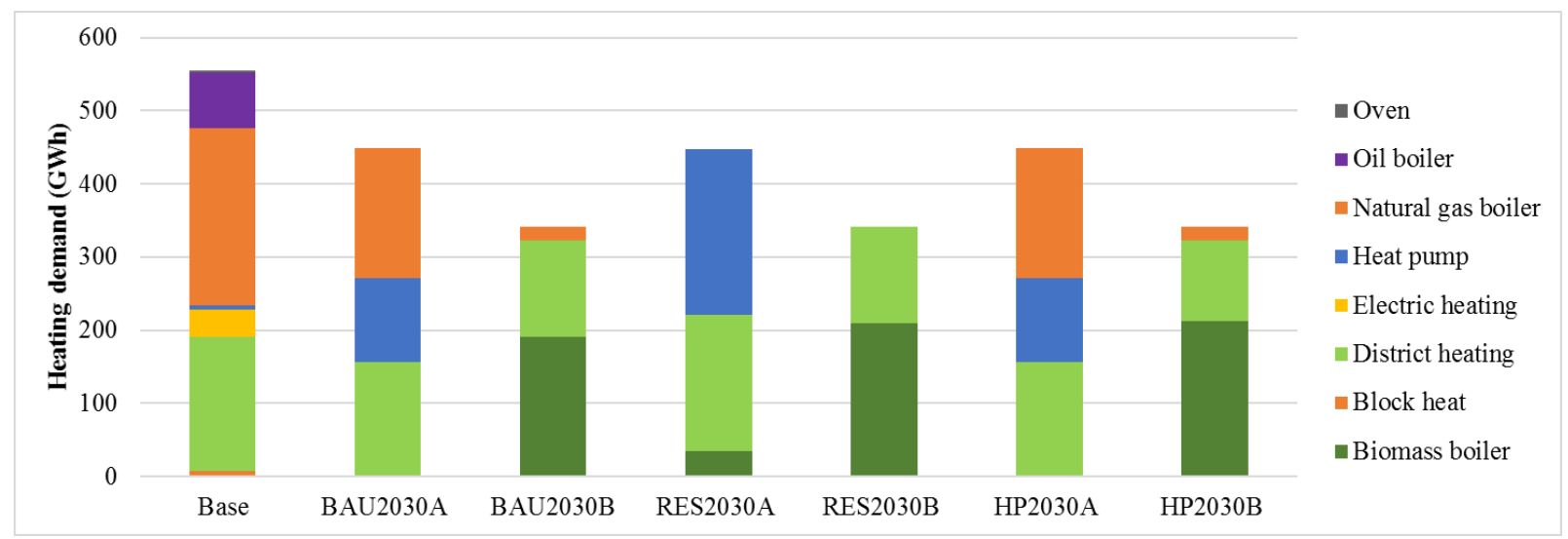

Fig. 6: Heat supply mix in the base and all 2030 scenarios (GWh)

In socio-economic scenarios, the heat supply mix is composed of individual natural gas boilers (about 30\%), individual ground-source heat pumps and district heating. In RES2030A scenario use of fossil fuels is not allowed, so instead of natural gas, the buildings are supplied by heat pumps and district heating. In the socio-economic scenarios, there is a clear geographical delineation of 
heat supply - district heating expands within existing district heating areas, but it does not pay off to expand it further. Natural gas boilers are supplying existing natural gas areas, while the remaining part of demand is covered by ground-source heat pumps. The reason for high costcompetitiveness of ground-source heat pumps lays in their high efficiency. In the present analysis it is assumed that residential heat pumps operate with the average annual electricity price. However, if heat pumps are operated flexibly they can achieve even higher cost-effectiveness.

In the private-economic scenarios, the optimal heat supply mix is dominated by individual biomass boilers and district heating, which cover around $56 \%$ and $40 \%$, respectively. The main reason for the high competitiveness of biomass boilers is that biomass is not taxed in Denmark. The price of biomass for the final consumer can increase in the future, either due to taxation or due to an increase in the world market prices. The influence of increased biomass prices is analysed in Section 4.5 .

The results show that in general heat pumps and district heating are more viable from the socioeconomic perspective, but biomass boilers are more viable from the private-economic perspective.

Figure 7 shows the heat supply mixes in the base year (results from 2030) and cost-optimal heat supply mixes for the two analysed scenarios in 2050.

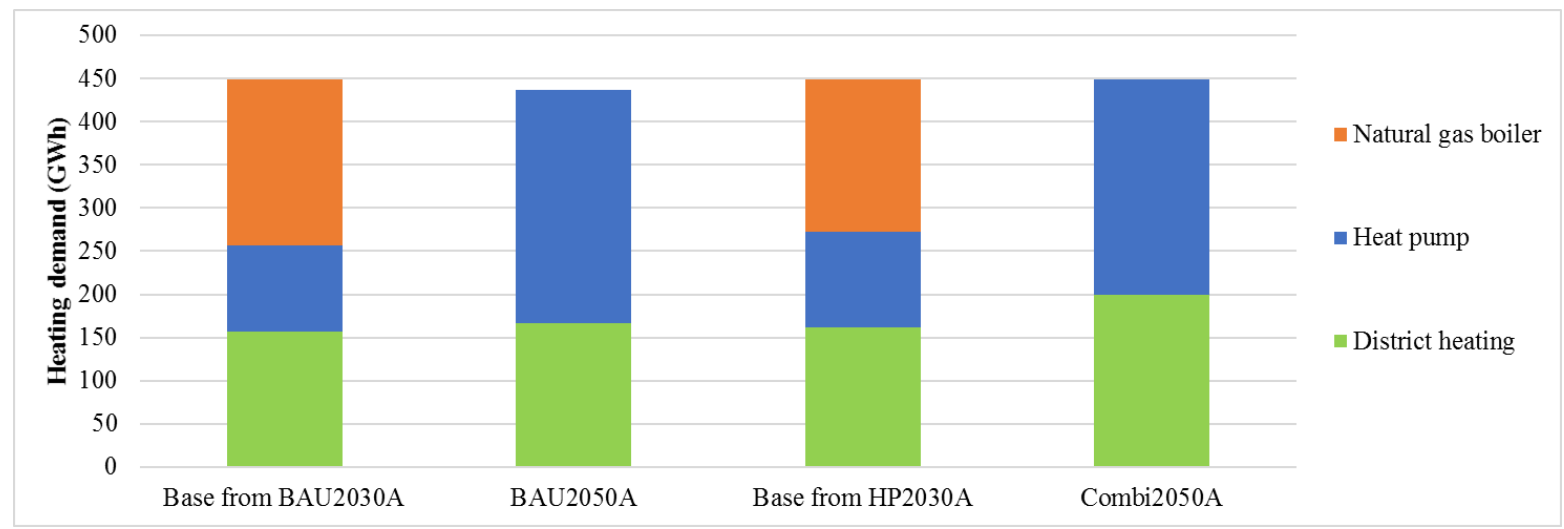

Fig. 7: Heat supply mix in the base and all 2050 scenarios $(\mathrm{GWh})$

The cost-optimal heat supply mix in both socio-economic scenarios is composed only of individual heat pumps and district heating - natural gas boilers are not part of the mix. This is however not the result of high heat supply cost but rather the restriction that fossil fuels cannot be used after 2035, which agrees with Danish and regional energy strategies.

\subsection{Heating costs}

Figure 8 depicts the calculated average heating costs per area type in Helsingør in the socioeconomic scenarios in 2030. The average heating costs represent the average costs for all the buildings located in an area. Heat savings are included in the same way as the heat supply technologies, i.e. annuitized price of saving $1 \mathrm{kWh}$ of heat is included in the average in the same way as the annuitized price of supplying $1 \mathrm{kWh}$ of heat. 


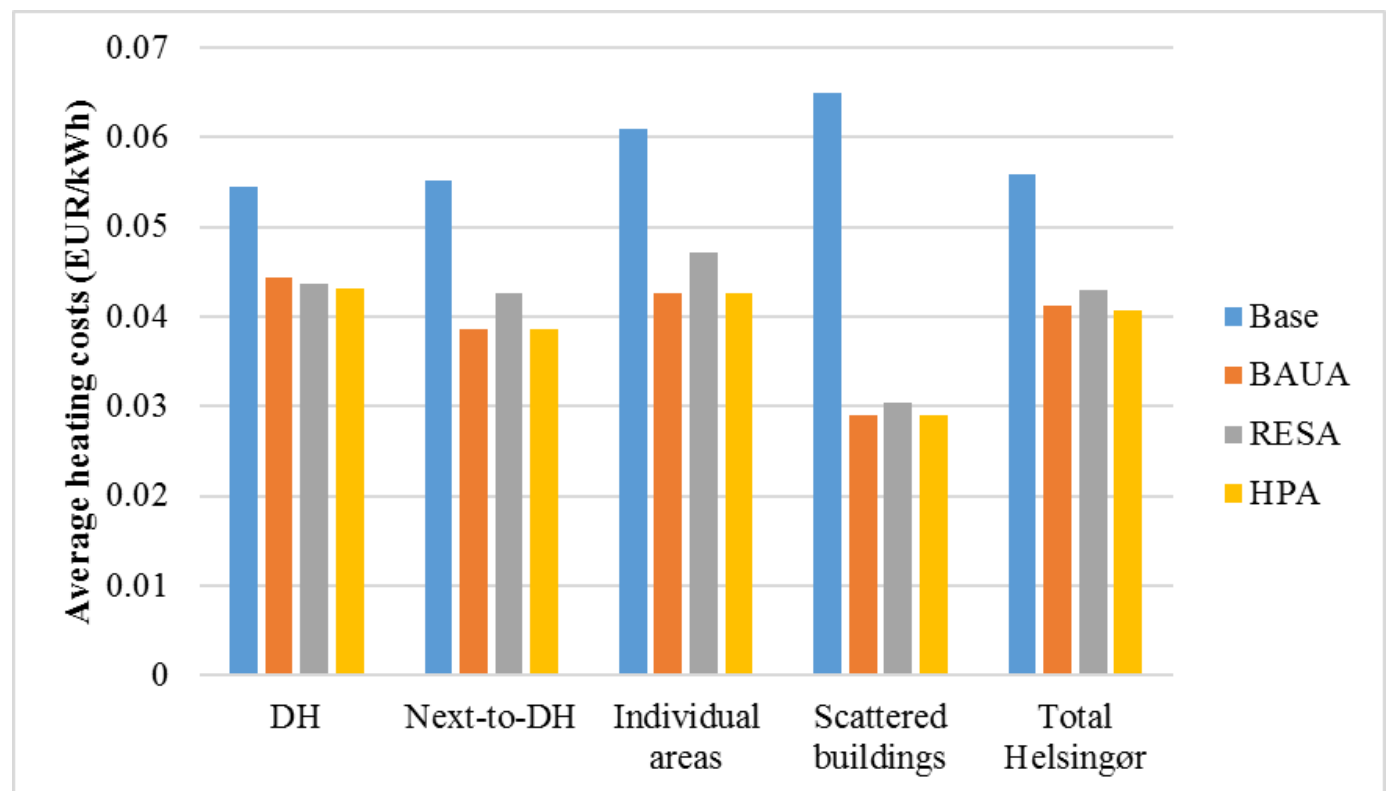

Fig. 8: Average heating costs in the base and in socio-economic scenarios BAU2030A, RES2030A and HP2030A (EUR/kWh)

The largest decrease in the heating price occurs within the Scattered buildings due to implementation of around $40 \%$ of heat savings. Scattered buildings are relatively old compared to the average age of the building stock in Helsingør. Therefore, the heat savings implemented in Scattered buildings appear to be least expensive. While the difference among 2030 scenarios is minor, the difference between current average heating price (Base) and the average heating price in renewable scenario is rather substantial.

Figure 9 depicts the calculated average heating costs per area type in Helsingør in the privateeconomic scenarios in 2030. The decrease of the average heating price (except in HPB scenario) is even higher than in the socio-economic scenarios and is around $40 \%$. Moreover, the price of RES scenario is almost the same as BAUB scenario; i.e. forbidding natural gas and oil boilers does not result in a higher cost compared to BAU scenario. Furthermore, HP scenario is more expensive than the other alternative scenarios and cannot be recommended from private-economic perspective. 


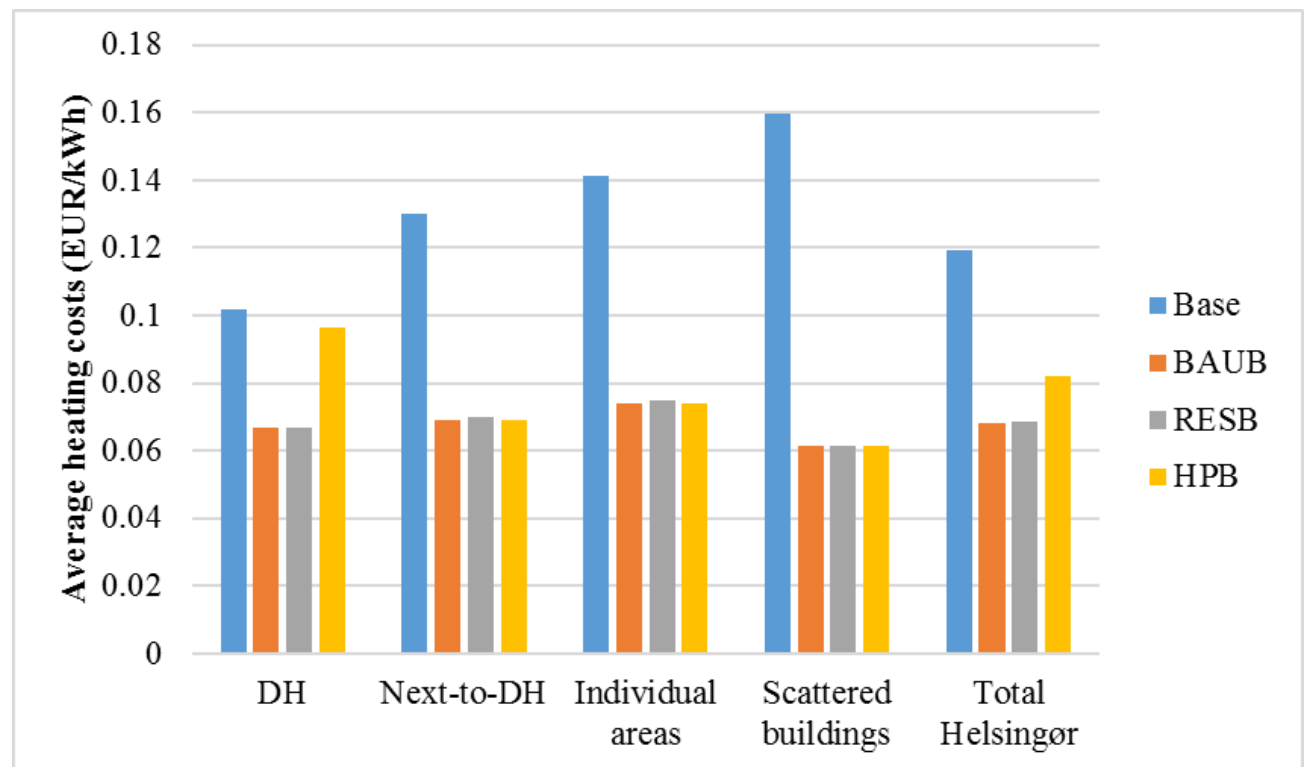

Fig. 9: Average heating costs in private-economic scenarios BAU2030B, RES2030B and HP2030B $(\mathrm{EUR} / \mathrm{kWh})$

Figure 10 shows the calculated average heating costs per area type in Helsingør in 2050. The Combi2050 scenario is less expensive both in total in Helsing $\varnothing \mathrm{r}$ and in all areas, mainly because the district heating price is lower in this scenario, resulting in higher DH share.

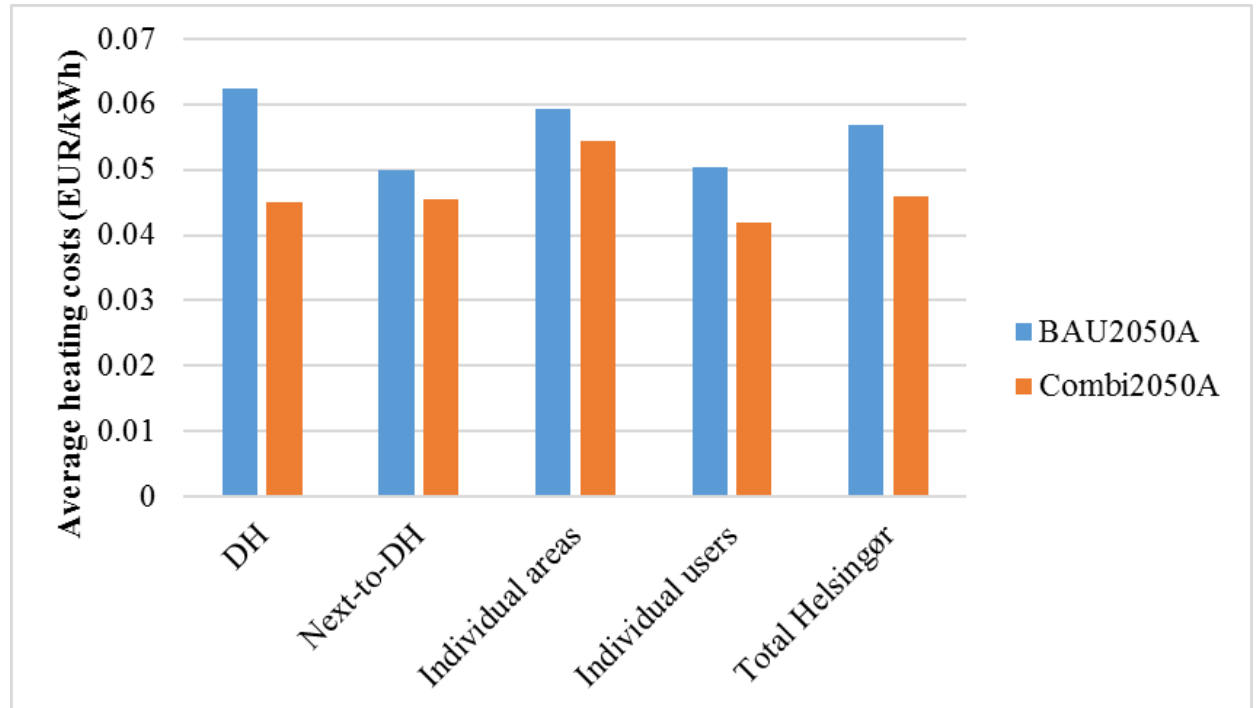

Fig. 10: Average heating costs in socio-economic scenarios BAU2050BA and Combi2050A (EUR/kWh)

\subsection{Share of district heating and heat savings}

The share of district heating in Helsingør in the base year is $33 \%$, which corresponds to the current share marked in Figure 11. The figure shows the resulting cost-optimal shares of district heating in 2030 in BAU, RES and HP scenarios from the socio- and private-economic perspectives. The share of district heating in district heating areas increases slightly in BAUA, RESA and RESB 
scenarios, while the growth of around $10 \%$ occurs in the remaining scenarios. The expansion of district heating within district heating areas is expected, since the investment needs to cover only the substation and connecting pipes. Further expansion, even within district heating areas is limited by price of competing technologies. For the municipality as a whole, the share of district heating increases in all scenarios, but only in RESA goes over $40 \%$, which is way below the Danish average of around 50\%. RESA scenario is the most favourable scenario for district heating and this is the only scenario where an expansion to the neighbouring areas is observed.

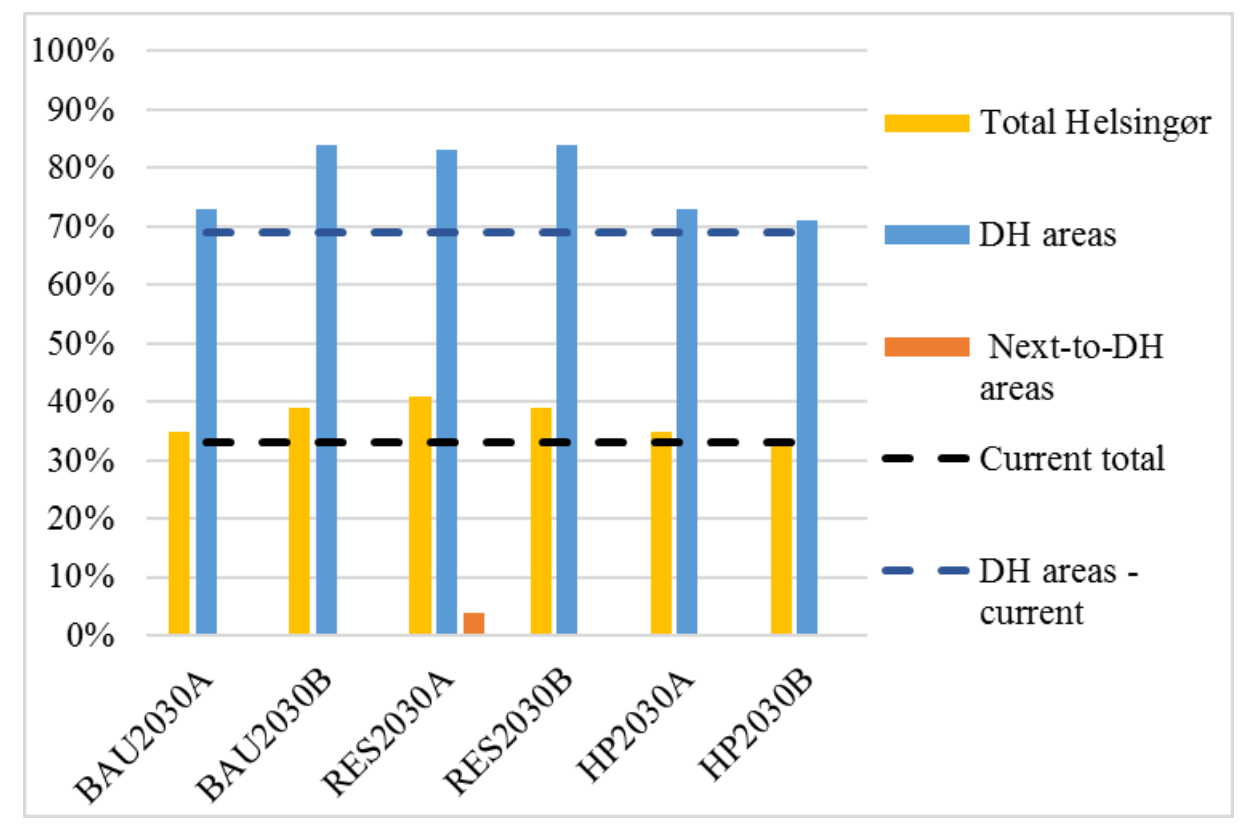

Fig 11.: Share of district heating in 2030 scenarios (\%)

Figure 12 depicts the share of district heating in 2050 scenarios. Due to low district heating price, Combi2050 results in higher than BAU2050 shares of district heating in each type of area and overall in Helsingør. 


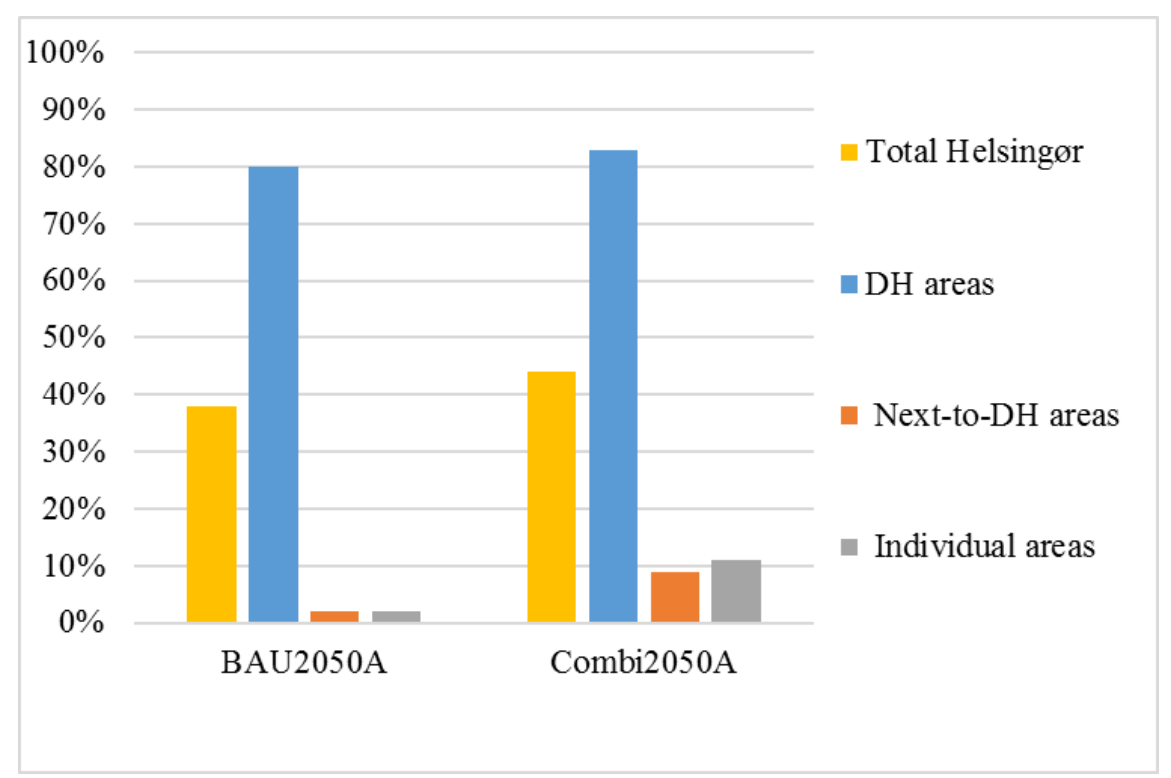

Fig.12: Share of district heating in 2050 scenarios (\%)

The reduction of heating demand in 2030 compared to the Base year is presented in Figure 13 for the six analysed scenarios. Heat savings occur in all scenarios - in the socio-economic ones (BAUA, RESA and HPA) they are around 18\%, while in the private-economic scenarios (BAUA, RESA and HPA) the heating demand is reduced by around $40 \%$.

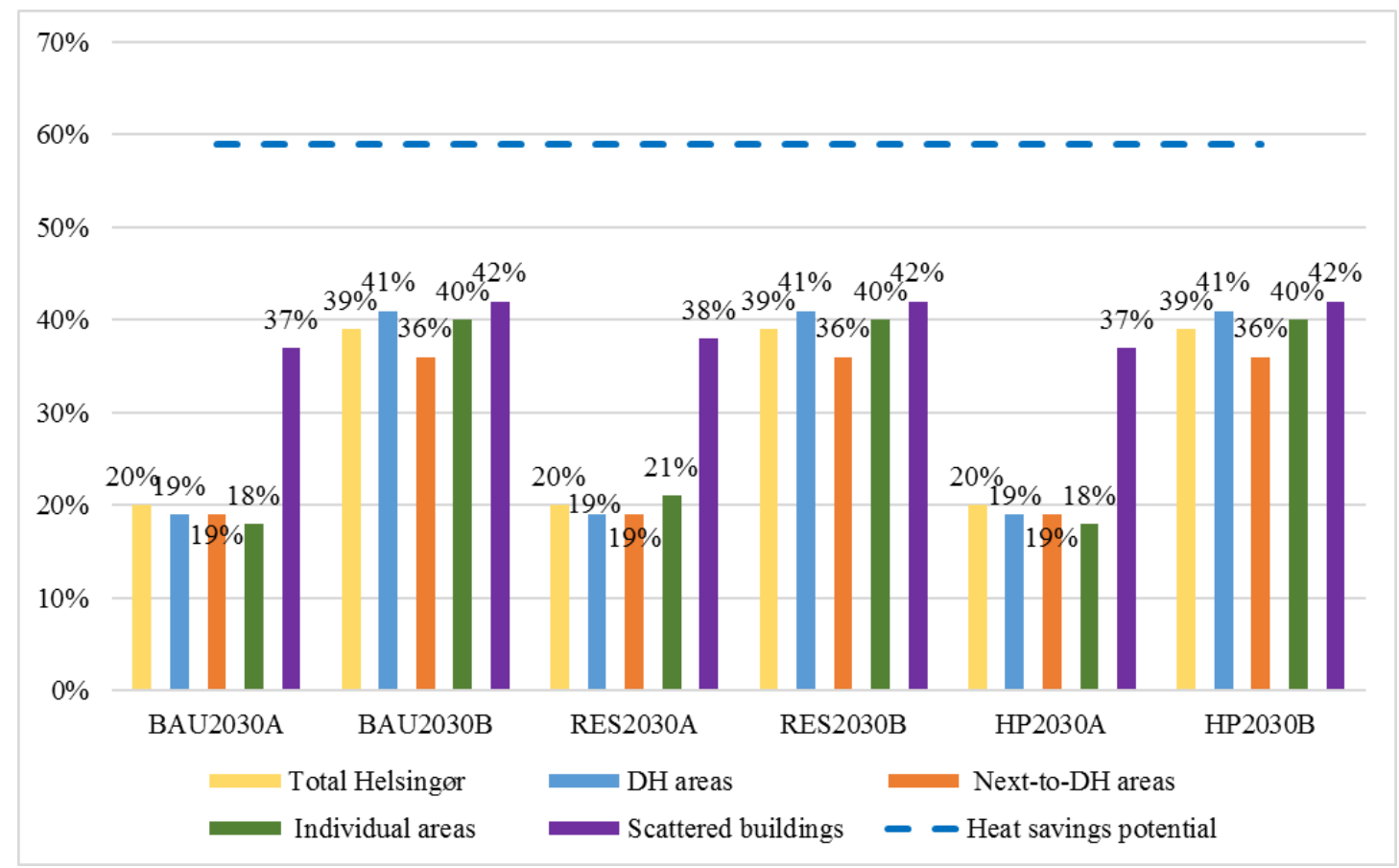

Fig.13: Share of district heating in 2050 scenarios (\%)

The maximum heat savings potential of 58\% (blue line in Figure 13) refers to the share of heat demand which can be reduced in the whole municipality on average; not in every individual type of areas. Two general observations can be drawn from the Figure 13. First, due to the fact that 
VAT is the only tax applied on heat savings, while the heat supply technologies (except biomass boilers) are also taxed on the input fuel (natural gas, oil, electricity, etc.), heat savings are more cost-competitive in private-economic scenarios than in socio-economic. Second, scattered buildings are mostly affected by heat savings. This is an expected result. On one hand, these buildings cannot be supplied by district heating and natural gas boilers. On the other hand, these buildings fall into groups of "Very old" and "Old" buildings, i.e. heat savings are relatively costeffective.

\subsection{Heating-related $\mathrm{CO}_{2}$ emissions}

The resulting $\mathrm{CO}_{2}$ emissions in the heating sector in 2030 compared to the Base year are shown in Figure 14. Substantial reductions occur in all scenarios, however RES2030 is optimal, achieving 95\% reduction. The only $\mathrm{CO}_{2}$ emissions originating from heat supply in case of this scenario are related to the amount of district heating coming from Norfors area, which is based on natural gas and MSW. These results correspond with heat supply mixes shown in Section 4.1.

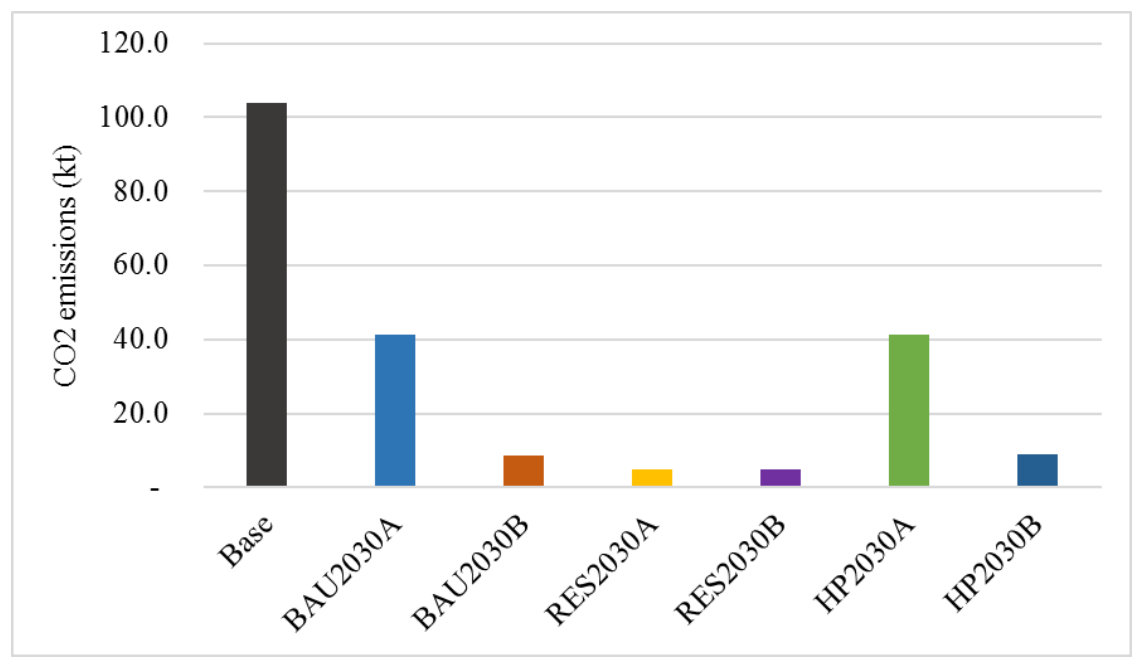

Fig. 14: $\mathrm{CO}_{2}$ emissions in 2030 scenarios (kt)

The resulting $\mathrm{CO}_{2}$ emissions in 2050 are presented in Figure 15. The results are the same in both scenarios, because we assume a constant amount of district heating supplied from the Norfors area. This is also the reason for no further emission reductions compared to e.g. scenario RES2030. 


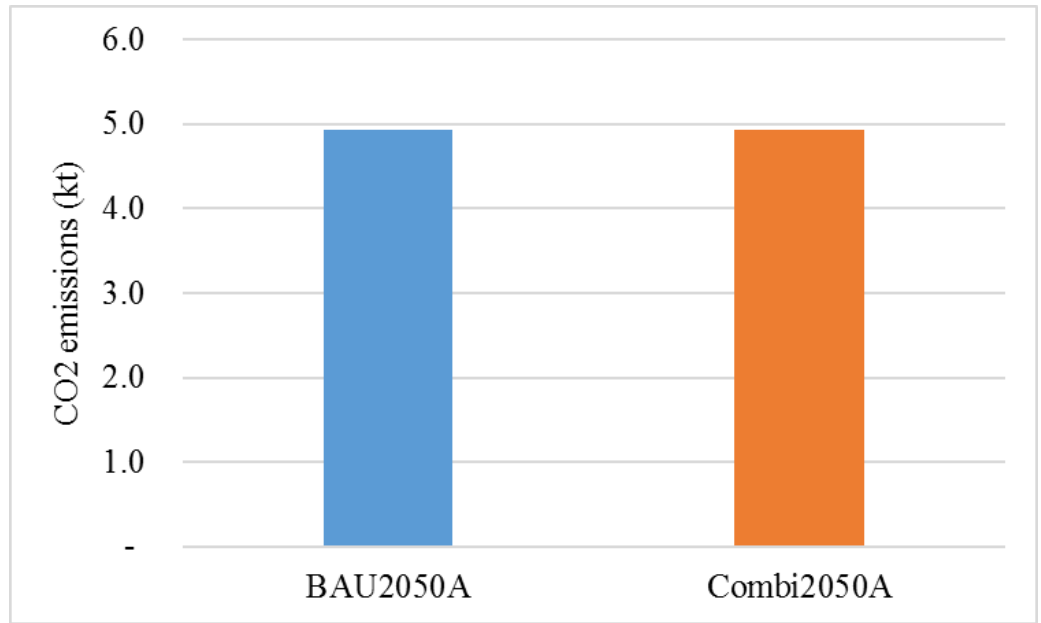

Fig. 15: $\mathrm{CO}_{2}$ emissions in 2050 scenarios (kt)

\subsection{Sensitivity analyses}

Biomass and electricity price are chosen for sensitivity analysis, since the examined scenarios are highly dependent on these resources. We discuss substantial changes in: district heating and heat savings share, heating costs and $\mathrm{CO}_{2}$ emissions.

\subsubsection{Increase and decrease of woodchips price}

Table 2 shows the results of the sensitivity analysis on the woodchip price for district heating plants and wood pellet price for individual boilers of the highly biomass-dependent scenarios.

Tab 2. Changes in $\mathrm{DH}$ share, heat savings share, heating costs and $\mathrm{CO}_{2}$ emissions due to increasing or decreasing biomass price in relation to price used in main scenarios.

\begin{tabular}{|c|c|c|c|c|c|}
\hline Scenario & $\begin{array}{l}\text { Biomass } \\
\text { price } \\
\text { change }\end{array}$ & $\begin{array}{l}\text { Change in } \\
\text { total DH } \\
\text { share }\end{array}$ & $\begin{array}{l}\text { Change in } \\
\text { total heat } \\
\text { savings } \\
\text { share }\end{array}$ & $\begin{array}{l}\text { Change in } \\
\text { total } \\
\text { heating } \\
\text { costs }\end{array}$ & $\begin{array}{l}\text { Change in } \\
\mathrm{CO}_{2} \\
\text { emissions }\end{array}$ \\
\hline \multirow[t]{2}{*}{ BAU2030A } & $+50 \%$ & $-1 \%$ & $0 \%$ & $0 \%$ & $+1 \%$ \\
\hline & $-50 \%$ & $+5 \%$ & $-19 \%$ & $-9 \%$ & $-85 \%$ \\
\hline \multirow{2}{*}{ BAU2030B } & $+\mathbf{5 0 \%}$ & $-7 \%$ & $+1 \%$ & $+11 \%$ & $285 \%$ \\
\hline & $-50 \%$ & $-5 \%$ & $-22 \%$ & $-18 \%$ & $-40 \%$ \\
\hline \multirow[t]{2}{*}{ RES2030A } & $+50 \%$ & $-5 \%$ & $+3 \%$ & $+7 \%$ & $0 \%$ \\
\hline & $-50 \%$ & $-1 \%$ & $-19 \%$ & $-14 \%$ & $+5 \%$ \\
\hline \multirow[t]{2}{*}{ RES2030B } & $+50 \%$ & $-7 \%$ & $+1 \%$ & $+10 \%$ & $+573 \%$ \\
\hline & $-50 \%$ & $-5 \%$ & $-22 \%$ & $-15 \%$ & $0 \%$ \\
\hline \multirow[t]{2}{*}{ BAU2050A } & $+50 \%$ & $-1 \%$ & - & $+18 \%$ & $0 \%$ \\
\hline & $-50 \%$ & $+8 \%$ & - & $-25 \%$ & $0 \%$ \\
\hline
\end{tabular}

Changes in total district heating share are minor in all scenarios. In socio-economic scenarios BAU2030A and BAU2050A a decreasing biomass price causes the district heating share to increase, the overall heating cost to decrease and the heat savings share to decrease as well. This 
is due to district heating based on biomass being less expensive than other options including heat savings.

In case of a biomass price decrease, both district heating price and individual biomass boiler heating price increase, resulting in selecting natural gas and heat pumps in this scenario and thus higher average heating price. A $50 \%$ biomass increase does not cause substantial changes in district heating, heat savings share or heating costs, except for BAU2050 scenario, where additional heat savings are not possible.

\subsubsection{Increase and decrease of electricity price}

Table 3 presents the results of the sensitivity analysis on the electricity price of the highly electricity-dependent scenarios.

Tab.3 Changes in DH share, heat savings share, heating costs and $\mathrm{CO}_{2}$ emissions due to increasing or decreasing electricity price in relation to price used in the main scenario.

\begin{tabular}{|l|l|l|l|l|l|}
\hline Scenario & $\begin{array}{l}\text { Electricity } \\
\text { price } \\
\text { change }\end{array}$ & $\begin{array}{l}\text { Change in } \\
\text { total DH } \\
\text { share }\end{array}$ & $\begin{array}{l}\text { Change in } \\
\text { total heat } \\
\text { savings } \\
\text { share }\end{array}$ & $\begin{array}{l}\text { Change in } \\
\text { total } \\
\text { heating } \\
\text { costs }\end{array}$ & $\begin{array}{l}\text { Change in } \\
\text { CO2 } \\
\text { emissions }\end{array}$ \\
\hline \multirow{2}{*}{ HP2030A } & $\mathbf{+ 5 0 \%}$ & $0 \%$ & $0 \%$ & $+6 \%$ & $+\mathbf{5 7 \%}$ \\
\cline { 2 - 6 } & $\mathbf{- 5 0 \%}$ & $+5 \%$ & $\mathbf{- 1 0 \%}$ & $\mathbf{- 7 \%}$ & $\mathbf{- 6 8 \%}$ \\
\hline \multirow{2}{*}{ HP2030B } & $\mathbf{+ 5 0 \%}$ & $0 \%$ & $0 \%$ & $+2 \%$ & $0 \%$ \\
\cline { 2 - 6 } & $\mathbf{- 5 0 \%}$ & $0 \%$ & $0 \%$ & $-2 \%$ & $0 \%$ \\
\hline \multirow{2}{*}{ Combi2050A } & $\mathbf{+ 5 0 \%}$ & $+3 \%$ & - & $\mathbf{+ 1 2 \%}$ & $0 \%$ \\
\cline { 2 - 6 } & $\mathbf{- 5 0 \%}$ & $-5 \%$ & - & $\mathbf{- 1 0 \%}$ & $0 \%$ \\
\hline
\end{tabular}

The total DH share does not substantially change due to the electricity price. However, changes in the socio-economic scenarios HP2030A and Combi2030A are more pronounced than in the private-economic scenario HP2030B, where electricity price changes are almost insignificant compared to the taxation levels. In HP2030A, the $\mathrm{CO}_{2}$ emissions are highly sensitive to the price - an increasing electricity price makes both district heating produced using heat pumps and individual heat pumps less profitable, causing more investments into natural gas boilers.

\section{Discussion}

A number of limitations occur in this study. The cost of heat saving measures adopted from the Invert/EE-Lab model are based on the assumption that heat savings will be implemented when the building is renovated anyway. In this way the cost include only the additional renovation costs related to energy savings, not the full costs. While for 2030, this assumption needs to be analysed further, for 2050, this assumption is in line with the Danish experience. Moreover, due to system boundary definition, we assume the Norfors system to remain the same; however, the possibility of new developments (renovations, changes in energy plant capacity). cannot be excluded. Thus, there may not be enough capacity in the system to expand DH as much, due to expansion in the connected system. Furthermore, in calculating individual heating cost for heat pumps, a yearly average electricity cost is assumed, which may not reflect the changes in electricity prices or the possibility to optimise the operation of heat pumps to hours with low prices. 
In all the analysed scenarios investments in new capacities are based on the assumptions about inflation and discount rates, thereby making these parameters crucial for the analysis. A number of assumptions were made regarding discount rates for private-economic analyses. The discount rate for district heating investments is calculated based on the assumption that the investment is financed partly from a municipal loan (currently 1.5\%) and partly overhead from municipalities $(0.5 \%)$ [40]. For the individual heating and heat savings the available discount rate rate is adjusted for the effect that part of the investment (33\%) is deducted from income tax (assuming income tax of $50 \%$ ), i.e. the reduction in income tax is reflected in the reduced interest rate. Two separate rates are calculated for individual heating supply and heat savings in larger and smaller buildings, because we assume that these two building groups have different loan conditions. For large buildings we assume that $80 \%$ is loan based on equity, $20 \%$ is the equity. For small buildings the assumption is that $100 \%$ is the loan based on equity of the house.

Since no further implementation of fossil fuels is planned in the municipality, a substantial decrease of $\mathrm{CO}_{2}$ emissions in heat supply is very plausible, no matter which scenario will be chosen. However, in case of the biomass CHP the feasibility of district heating expansion depends very much on which prices the future district heating will be able to offer and how taxation (including tax exemption for biomass) will be shaped. Other examples are: future fuel and technology prices, as well as policies including $\mathrm{CO}_{2}$ targets.

The viability of the scenarios proposed depends also on the availability of the locally available renewable energy resources. Other scenarios benefit from less dependence on biomass and by not bearing the risk of the biomass price increases. Besides, looking from overall sustainability perspective, biomass should preferably be used in sectors such as heavy transport which currently does not have other $\mathrm{CO}_{2}$-free solutions.

Since the possibility of DH disconnection is excluded, high shares of heat savings are implemented even in district heating areas. However, allowing disconnection could affect these shares.

The role of energy taxation is important. Our results differ, depending on whether taxes are considered or not. For example, private-economically, heat savings pay off more.

The sensitivity analysis conducted shows that the change of electricity and biomass prices influences mainly the heating costs and $\mathrm{CO}_{2}$ emissions, which in turn is linked to different fuel mixes than in the main scenarios.

The goals of Helsingør reaching a level of one tonne of $\mathrm{CO}_{2} /$ inhabitant in 2030 and becoming $\mathrm{CO}_{2}$ neutral in 2050 are achievable in the heating sector, independently from scenario - but certainly, choosing scenarios with lowest emissions such as RES2020 will allow faster transition to sustainability or offsetting emissions from other sectors, e.g. transport. This will in turn require the municipality to propose a ban on fossil fuel-based individual heat supply, which may be difficult to implement in practice. 


\section{Conclusions}

In this study, we developed a methodology for deriving an optimal mix of heat savings, district heating expansion and individual heat supply, using the spreadsheet-based Least Cost Tool (LCT) and energyPRO modelling tool. We applied this methodology in the municipality of Helsingør, Denmark.

From the socio-economic perspective, the highest district heating share $(41 \%)$ and lowest $\mathrm{CO}_{2}$ emissions (5kt) occur in the RES2030A scenario, where a policy of forbidding oil and natural gas boilers is applied. For the municipality as a whole, the share of district heating only in RES2030A exceeds 40\%, which is below the Danish average of around 50\%. RES2030A is the only scenario where an expansion to the neighbouring areas is observed. Moreover, the RES2030A scenario has the same low average heating cost as the BAU2030 scenario. From the private-economic perspective, the scenario resulting in highest district heating share (39\%) and lowest $\mathrm{CO}_{2}$ emissions is the RES2030B scenario - it also results in low average heat price equal to BAU2030B scenario. Thus, this is the most feasible scenario for Helsingør in 2030, considering both economic and environmental aspects. In 2050, the Combi scenario is more viable than BAU considering the district heating share and heating cost.

Heat demand reduction due to heat savings is the same for each scenario, however higher from the private-economic perspective, where it is feasible to save almost $40 \%$ of heat demand in each area.

A possibility for substantial $\mathrm{CO}_{2}$ reduction exists in Helsingør, contributing to fulfilling the municipality's aspirations of reaching a level of one tonne of $\mathrm{CO}_{2} /$ inhabitant in 2030 and becoming $\mathrm{CO}_{2}$ neutral in 2050. A 95\% $\mathrm{CO}_{2}$ emission reduction occurs in the scenarios RES2030A and RES2030B. Both 2050 scenarios: BAUA and Combi achieve the same $\mathrm{CO}_{2}$ level as RES2030, due to the constant amount of heat supplied from the Norfors area, which is based on MSW and natural gas.

Since the Combi2050 scenario is socio-economically an optimal solution for Helsingør in 2050, we recommend that the operation of an already decided biomass CHP plant is closely monitored and new technologies such as heat pumps and heat storages are considered in the 10-15 years' perspective. The uncertainty connected to future biomass taxation is rather high. If electricity taxation changes in the future, considering large heat pumps is important. Many district heating companies in Denmark also invest in solar thermal installation and this technology should be considered as well.

Although the findings of the study are mainly applicable for Helsingør, they can be representative for towns of similar size, climate conditions, access to natural resources and district heating share. Moreover, the iterative method for calculating the optimal heat supply configuration can be useful in energy planning of any heating system type, geographical region and scale. Furthermore, the paper displays solutions that may encourage other cities to conduct local energy planning.

Future work will concentrate on policy analyses such as the influence of tax alternation and subsidies on the profitability of heat supply and heat savings options in Helsingør. 


\section{Acknowledgements}

We would like to thank Lukas Kranzl, Marcus Hummel and Richard Büchele from TU Wien, Tobias Fleiter and Ali Aydemir from Fraunhofer ISI and Lena Kitzing from the Department of Management Engineering at DTU for supplying data and participating in methodology discussions. We are also grateful to Karen Marie Pagh Nielsen and Leif Westen from Helsingør municipality for valuable data and discussions. This work has received funding from the European Union's Horizon 2020 research and innovation programme within the progRESsHEAT project and from the Department of Management Engineering at the Technical University of Denmark within the PhD project entitled "Urban energy transitions and quality of life".

\section{References}

[1] European Technology Platform on Renewable Heating and Cooling. 2020-2030-2050 Common Vision for the Renewable Heating \& Cooling sector in Europe. 2011. doi:10.2788/20474.

[2] Chittum A, Østergaard PA. How Danish communal heat planning empowers municipalities and benefits individual consumers. Energy Policy 2014;74:465-74. doi:10.1016/j.enpol.2014.08.001.

[3] Danish Energy Agency. Strategisk energiplanlægning i kommunerne. Kortlægning og nøgletal. Vejledning i kortlægningsmetoder og datafangst (Strategic energy planning in municipalities. Mapping and key numbers. Guide in mapping methods and data collection). 2012.

[4] Bertoldi P, Bornas Cayuela D, Monni S, Piers De Raveschoot R. How to develop a Sustainable Energy Action Plan (SEAP) - Guidebook. 2010. doi:10.2790/20638.

[5] Kona A, Melica G, Calvete SR, Zancanella P, Iancu A, Saheb Y et al. The Covenant of Mayors in Figures and Performance Indicators: 6-year Assessment. 2015. doi:10.2790/774700.

[6] Sperling K, Möller B. End-use energy savings and district heating expansion in a local renewable energy system - A short-term perspective. Appl Energy 2012;92:831-42. doi:10.1016/j.apenergy.2011.08.040.

[7] Østergaard PA, Lund H. A renewable energy system in Frederikshavn using lowtemperature geothermal energy for district heating. Appl Energy 2011;88:479-87. doi:10.1016/j.apenergy.2010.03.018.

[8] Xydis G. Development of an integrated methodology for the energy needs of a major urban city: The case study of Athens, Greece. Renew Sustain Energy Rev 2012;16:6705-16. doi:10.1016/j.rser.2012.09.003.

[9] Sampaio HC, Dias RA, Balestieri JAP. Sustainable urban energy planning: The case study of a tropical city. Appl Energy 2013;104:924-35. doi:10.1016/j.apenergy.2012.12.022.

[10] Comodi G, Cioccolanti L, Gargiulo M. Municipal scale scenario: Analysis of an Italian seaside town with MarkAL-TIMES. Energy Policy 2012;41:303-15. doi:10.1016/j.enpol.2011.10.049.

[11] Juroszek Z, Kudelko M. A model of optimization for local energy infrastructure development. Energy 2016;96:625-43. doi:10.1016/j.energy.2015.12.083.

[12] Keirstead J, Jennings M, Sivakumar A. A review of urban energy system models: Approaches, challenges and opportunities. Renew Sustain Energy Rev 2012;16:3847-66. 
doi:10.1016/j.rser.2012.02.047.

[13] Calvillo CF, Sánchez-Miralles A, Villar J. Energy management and planning in smart cities. Renew Sustain Energy Rev 2016;55:273-87. doi:10.1016/j.rser.2015.10.133.

[14] Stennikov VA, Iakimetc EE. Optimal planning of heat supply systems in urban areas. Energy 2016;110:157-65. doi:10.1016/j.energy.2016.02.060.

[15] Karlsson KB, Petrović SN, Næraa R. Heat supply planning for the ecological housing community Munksøgård. Energy 2016. doi:10.1016/j.energy.2016.08.064.

[16] Morvaj B, Evins R, Carmeliet J. Optimising urban energy systems: Simultaneous system sizing, operation and district heating network layout. Energy 2016;116:619-36. doi:10.1016/j.energy.2016.09.139.

[17] Harrestrup M, Svendsen S. Heat planning for fossil-fuel-free district heating areas with extensive end-use heat savings: A case study of the Copenhagen district heating area in Denmark. Energy Policy 2014;68:294-305. doi:10.1016/j.enpol.2014.01.031.

[18] Bach B, Werling J, Ommen T, Münster M, Morales JM, Elmegaard B. Integration of largescale heat pumps in the district heating systems of Greater Copenhagen. Energy 2016;107:321-34. doi:10.1016/j.energy.2016.04.029.

[19] Nielsen S, Möller B. GIS based analysis of future district heating potential in Denmark. Energy 2013;57:458-68. doi:10.1016/j.energy.2013.05.041.

[20] Østergaard PA. Comparing electricity, heat and biogas storages' impacts on renewable energy integration. Energy 2012;37:255-62. doi:10.1016/j.energy.2011.11.039.

[21] Streckienė G, Martinaitis V, Andersen AN, Katz J. Feasibility of CHP-plants with thermal stores in the German spot market. Appl Energy 2009;86:2308-16. doi:10.1016/j.apenergy.2009.03.023.

[22] Fragaki A, Andersen AN. Conditions for aggregation of CHP plants in the UK electricity market and exploration of plant size. Appl Energy 2011;88:3930-40. doi:10.1016/j.apenergy.2011.04.004.

[23] Sorknæs P, Lund H, Andersen AN. Future power market and sustainable energy solutions - The treatment of uncertainties in the daily operation of combined heat and power plants. Appl Energy 2015;144:129-38. doi:10.1016/j.apenergy.2015.02.041.

[24] Sorknæs P, Lund H, Andersen AN, Ritter P. Small-scale combined heat and power as a balancing reserve for wind - The case of participation in the German secondary control reserve. Int J Sustain Energy Plan Manag 2015;4:31-42.

[25] Kiss VM. Modelling the energy system of Pécs - The first step towards a sustainable city. Energy 2015;80:373-87. doi:10.1016/j.energy.2014.11.079.

[26] progRESs HEAT. EU Horizon 2020 project progRESs HEAT n.d. http://www.progressheat.eu/.

[27] Nielsen S, Möller B. Excess heat production of future net zero energy buildings within district heating areas in Denmark. Energy 2012;48:23-31. doi:10.1016/j.energy.2012.04.012.

[28] Ea Energianalyse. Lokale vedvarende energiressourcer. Potentialevurdering til "Energi på tværs" (Local renewable energy sources. Potential assesment for "Energi på tværs" project). 2015.

[29] Lund R, Persson U. Mapping of potential heat sources for heat pumps for district heating in Denmark. Energy 2016;110:129-38. doi:10.1016/j.energy.2015.12.127.

[30] Drupp, MA, Freeman, MC, Groom, B, Nesje F. Discounting Disentangled. Memorandum No 20/2015, Department of Economics, University of Oslo. 2015. 
[31] Aftale mellem regeringen ( Socialdemokraterne, Det Radikale Venstre , Socialistisk Folkeparti ) og Venstre , Dansk Folkeparti , Enhedslisten og Det Konservative Folkeparti om den danske energipolitik 2012-2020 Et energieffektivt samfund med mindre energi 2012:1-16.

[32] Danish Energy Agency, Energinet.dk. Technology data for energy plants. Generation of electricity and district heating, energy storage and energy carrier generation and conversion (updated 2015). 2012. doi:ISBN: 978-87-7844-931-3.

[33] Energinet.dk. Analyseforudsætninger 2015-2035 (Analysis assumptions for 2015-2035). 2015.

[34] Eurostat. Energy price statistics 2013. http://ec.europa.eu/eurostat/statisticsexplained/index.php/Energy_price_statistics.

[35] European Commission. EU Reference Scenario 2016. 2016.

[36] Danish Energy Agency, Energinet.dk. Technology data for energy plants. Individual heating plants and energy transport 2012.

[37] Invert/EE-Lab. 2015 n.d.

[38] Persson U, Werner S. Heat distribution and the future competitiveness of district heating. Appl Energy 2011;88:568-76. doi:10.1016/j.apenergy.2010.09.020.

[39] EMD International. EMD International n.d.

[40] EY. Kortlægning af kommunale garantiprovisioner for låntagning i forsyningsselskaber (Mapping of municipal guarantee commissions for borrowing by utilities). 2016.

[41] Energistyrelsen. Standardfaktorer for brændværdier og CO2 emissioner (Standard factors for calorific value and CO2 emissions). 2015. 


\section{Appendix A Prices and tax rates}

Tab. A.1 Fuel prices excl. taxes in 2030 and in 2050

\begin{tabular}{|c|c|c|}
\hline & Year 2030 & Year 2050 \\
\hline Fuel type & Price (EUR/MWh) & Price (EUR/MWh) \\
\hline Natural gas & 2.67 & 3.28 \\
\hline Wood chips & 2.16 & 3.39 \\
\hline Oil & 63.0 & 73.0 \\
\hline
\end{tabular}

Tab. A.2 Tax rates

\begin{tabular}{|c|c|}
\hline Type of tax & Tax rate \\
\hline Energy tax on natural gas consumption for heat & $0.37 \mathrm{EUR} / \mathrm{Nm}^{3}$ \\
\hline Energy tax on natural gas consumption for heat in engines & $0.39 \mathrm{EUR} / \mathrm{Nm}^{3}$ \\
\hline $\mathrm{CO}_{2}$ tax on natural gas consumption for heat & $0.05 \mathrm{EUR} / \mathrm{Nm}^{3}$ \\
\hline $\mathrm{CO}_{2}$ tax on natural gas consumption in engines & $0.01 \mathrm{EUR} / \mathrm{Nm}^{3}$ \\
\hline $\begin{array}{c}\text { Methane tax on natural gas consumption of stationary } \\
\text { piston engines }\end{array}$ & $0.05 \mathrm{EUR} / \mathrm{Nm}^{3}$ \\
\hline NOx tax on natural gas (per measured emissions) & $3.42 \mathrm{EUR} / \mathrm{kg} \mathrm{NOx}$ \\
\hline Energy tax on heat produced from waste incineration & $3.49 \mathrm{EUR} / \mathrm{GJ}$ \\
\hline Supplementary energy tax on amount of waste used as fuel & $4.27 \mathrm{EUR} / \mathrm{GJ}$ \\
\hline $\begin{array}{c}\text { Heat pumps: various taxes (PSO, distribution etc.) on } \\
\text { large-scale heat pumps (per MWh consumed electricity) }\end{array}$ & $119 \mathrm{EUR} / \mathrm{MWh}$ \\
\hline
\end{tabular}

\section{Appendix $\mathrm{B} \mathrm{CO}_{2}$ emission factors and energy content of fuels}

Tab. B.1 $\mathrm{CO}_{2}$ factors [41]

\begin{tabular}{|c|c|}
\hline Fuel & CO$_{2}$ factor \\
\hline Natural gas & $56.95 \mathrm{t} / \mathrm{TJ}$ \\
\hline Oil & $77.4 \mathrm{t} / \mathrm{TJ}$ \\
\hline
\end{tabular}

Table B.2 Energy content of fuels [41]

\begin{tabular}{|c|c|c|}
\hline Fuel & Value & Unit \\
\hline Natural gas & 0.04 & $\mathrm{GJ} / \mathrm{Nm}^{3}$ \\
\hline Wood chips & 9.3 & $\mathrm{GJ} / \mathrm{t}$ \\
\hline Waste & 10.6 & $\mathrm{GJ} / \mathrm{t}$ \\
\hline
\end{tabular}

\section{Appendix C Calculation of the price of heat}




$$
\begin{gathered}
H C=\frac{C R F \cdot C_{I}+C_{O \& M}+C_{f u e l}+C_{\text {tax }}}{H D} \\
\text { CRF }=\frac{i \cdot(1+i)^{n}}{(1+i)^{n}-1},
\end{gathered}
$$

CRF- Capital recovery factor

$\mathrm{i}$ - interest rate

$\mathrm{n}-$ economic lifetime

HC- Heat cost

$\mathrm{C}_{\mathrm{I}}, C_{O \& M}, C_{f u e l}, C_{t a x}$-investment and O\&M (operation and maintenance) costs in 2015, fuel costs from 2030 and taxes. 